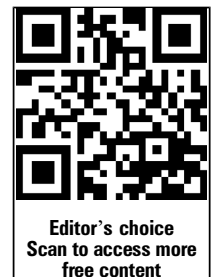

free content

SHORT REPORT

\title{
Results from a project to develop systematic patient focused clinical pharmacy services. The Lund Integrated Medicines Management model
}

\author{
Tommy Eriksson
}

\section{Correspondence to Dr T Eriksson, Department of Clinical Pharmacology, Lund University, Lund 22100 , Sweden; tommy.eriksson@ med.lu.se}

Received 7 May 2013 Accepted 9 September 2013 Published Online First 30 September 2013
To cite: Eriksson T. Eur J Hosp Pharm 2014;21: 121-124.

\section{BACKGROUND}

As people get older, polypharmacy increases and there is an increased risk of adverse drug events, drug interactions, low medication adherence, increasing economic burden, hospital admissions and even drug-related deaths. ${ }^{1}$ It has also been stated that the problems of inappropriate pharmacotherapy are expected to grow in the future as new drugs are introduced, new uses for old drugs are found and as the population lives longer with an increased risk of chronic medical conditions. Poor communication of medical information suggests that $40-85 \%$ of elderly patients have at least one error in their medications when they are transferred between primary and hospital care. ${ }^{2-6}$ In order to improve quality in the use of medications in society, and for individual patients, there is a need to identify problems and errors in structures and processes to improve the outcome of care and to reduce errors. ${ }^{7}$

A systematic analysis of potential problems and limitations during the standard patient medication care process was performed by the Drug and Therapeutics Committee at Lund University Hospital in 1999. This followed admission, hospital stay and post discharge. After confirmation of the problems, a project was initiated. The aim was to build a model based on systematic training, activities and responsibilities, to identify, solve and prevent drug related problems (DRPs) in the healthcare process, starting from when a patient is admitted to hospital. For patient based clinical pharmacy services, we identified no systematic research or models focusing on all of these aspects.

Herein is an overview of the results which have been published in 17 separate publications. ${ }^{2-6} 8-19$ Readers are encouraged to follow-up specific results by referring to tables 2 and 3 for the referenced summary.

\section{METHODS}

A systematic analysis of potential problems and limitations during the standard patient medication care process was performed in 1999. This followed admission, hospital stay and post discharge. We focused initially on the potential problems to assess their frequency and clinical significance. We also began to improve the structure and process for each of the three stages (admission, hospital stay and post discharge) to improve patient and healthcare outcomes. For each part, specific tools, checklists and responsibilities were developed and subsequently tested. The final structured model is team based and consists of systematic medication reconciliation, medication review, and oral and written communication, as described in figure 1 and table 1 . The clinical pharmacist was the catalyst for improvement in the patient care team but each member had their specific responsibilities, and the physician was responsible for changes in prescribing. Each part of the model was developed, introduced into the care team and researched stepwise in cooperation with the key teams: pharmacy, medicine and nursing, in hospital and primary care. The project was based on internal medicine wards at Skåne University Hospital, Lund and Landskrona Hospital, Sweden.

We used descriptive studies to investigate problems, comparative controlled studies to investigate improvements, and blinded evaluators for studies on errors, consequences and clinical significance. Where possible we used validated tools; if not, we developed and validated new tools. The study size was based on power calculations where applicable. We analysed results using descriptive and comparative statistics, trend, regression and survival analysis, intention to treat and per protocol analysis, and also probabilistic decision tree models for health economic evaluations. The number of included patients in each of the studies ranged from $<100$ to almost 4000.

\section{RESULTS}

Nineteen scientific publications and manuscripts have been produced from the development, and also formed the basis for four $\mathrm{PhD}$ and more than 30 MSc theses. The model has been shown to improve the process of care-that is, it identifies and solves DRPs, reduces medication reconciliation errors and improves medication appropriateness. A summary of the benefits in the admission and hospital care process is presented in table 2 and in the discharge process in table 3 . For each comparison, there was significant improvement (at least at the $\mathrm{p}<0.05$ level).

The model also improved clinical outcome. Healthcare contacts and hospital readmissions due to medication errors were reduced by at least $50 \%{ }^{13} \quad 16$ but total readmissions were not affected. ${ }^{14}$ It also saved time, at least $2-3 \mathrm{~h}$ per patient, for physicians and nurses in hospitals, in primary and community care. ${ }^{17}$ The model also generated cost savings of $€ 370$, for each intervention cost of $€ 42$ and gained utility of $0.005 .{ }^{18}$ The 
Table 1 The Lund Integrated Medicines Management model: activities performed in the hospital wards, responsible professional groups and tools for performing the activities

\begin{tabular}{|c|c|c|c|}
\hline When and how often & Activity & Responsibility & Tool \\
\hline $\begin{array}{l}\text { At admission, once for each } \\
\text { patient }\end{array}$ & Admission medication reconciliation & Clinical pharmacist & $\begin{array}{l}\text { LIMM Medication Interview Questionnaire, parts 1-3, } \\
\text { depending on medication, disease and patient } \\
\text { characteristics. } \\
\text { Part 1: identification of the most accurate patient } \\
\text { medication list } \\
\text { Part 2: addition of questions concerning practical } \\
\text { handling, knowledge and adherence } \\
\text { Part 3: addition of deeper questions concerning } \\
\text { adherence and beliefs }\end{array}$ \\
\hline \multirow[t]{2}{*}{$\begin{array}{l}\text { During hospital stay, } \\
\text { continuously for each } \\
\text { patient }\end{array}$} & $\begin{array}{l}\text { Medication review and monitoring } \\
\text { Symptom assessment }\end{array}$ & $\begin{array}{l}\text { Clinical pharmacist } \\
\text { Nurse (or clinical } \\
\text { pharmacist) }\end{array}$ & $\begin{array}{l}\text { LIMM medication review form } \\
\text { LIMM symptom assessment form }\end{array}$ \\
\hline & $\begin{array}{l}\text { Lead the team and organise a treatment plan based on } \\
\text { symptom assessment, the medication review and } \\
\text { reconciliation }\end{array}$ & Physician & Documented in the patient health record \\
\hline $\begin{array}{l}\text { At discharge, once for each } \\
\text { patient }\end{array}$ & Discharge medication reconciliation & Physician & $\begin{array}{l}\text { LIMM discharge information form, including a } \\
\text { medication report and a medication list }\end{array}$ \\
\hline At regular intervals & Quality control of discharge medication reconciliation & Clinical pharmacist & $\begin{array}{l}\text { LIMM quality control form for discharge medication } \\
\text { reconciliation }\end{array}$ \\
\hline
\end{tabular}

LIMM, Lund Integrated Medicines Management.

probability that the intervention would be cost effective at a zero willingness to pay for a quality adjusted life year gain was $98 \%$. Finally, physicians and nurses were very satisfied with the process and the pharmacist contribution. ${ }^{10} 1117$ The model has been adapted to primary care medication review by pharmacists, and a randomised controlled study showed a decrease in potential inappropriate medication among the elderly. ${ }^{19}$

\section{DISCUSSION}

For more than a decade, the Lund Integrated Medicines Management (LIMM) model has been developed and researched, and its benefit in the process and in some outcomes has been established using high quality methods and design for a team approach. During this period, several hundred pharmacists, physicians and nurses have been involved. Although the pharmacist is the catalyst and the lead professional in getting the process running, the roles of the physicians and nurses are fundamental for success. The model is transferable to similar healthcare systems, and outcomes can be guaranteed with the use of the tools, checklists and other support systems developed using LIMM process indicators and standards.

A recent Cochrane review concluded that it is uncertain whether medication review reduces mortality or hospital readmissions, but medication review seems to reduce emergency department contacts. ${ }^{1}$ However, the cost effectiveness of this intervention is not known, and due to the uncertainty of the

Table 2 Activities on admission and during hospital stay: summary of potential process benefits studied

\begin{tabular}{|c|c|}
\hline Potential benefit & Results and references \\
\hline The clinical pharmacist identifies DRPs systematically & $\begin{array}{l}\text { A mean } 1.9 \text { DRPs (mainly errors in medication lists) were identified using the LIMM MIF part } 1 . \text { They } \\
\text { also identified a mean } 7.6 \text { DRPs using the LIMM MRF. } \\
\text { MIF parts } 1-3 \text { can be used clinically and for research purposes. }{ }^{9} \\
\text { The clinical pharmacist identified a mean } 6.5 \text { DRPs using the MIF and } \text { MRF }^{10}\end{array}$ \\
\hline Identifies errors that would not be identified by standard care & $\begin{array}{l}\text { Using MIF part } 1 \text {, a mean of } 1 \text { error in medications lists was identified which normally would not be } \\
\text { identified by standard care. } \\
\text { Using MRF and LIMM symptom assessment form, } 8 \text { DRPs were identified which would not be } \\
\text { identified by standard care. }{ }^{11}\end{array}$ \\
\hline $\begin{array}{l}\text { Recommendations from the pharmacist to the physician to solve } \\
\text { and prevent DRPs is performed systematically }\end{array}$ & $\begin{array}{l}81 \% \text { and } 62 \% \text { of real DRPs identified using MIF part } 1 \text { and MRF, respectively, were presented and } \\
\text { recommended. }^{8} \\
56 \% \text { of all DRPs identified using MIF part } 1 \text { and MRF were presented and recommended }{ }^{10}\end{array}$ \\
\hline $\begin{array}{l}\text { The physician completes the pharmacist's recommendations } \\
\text { systematically }\end{array}$ & $90 \%{ }^{8}$ and $64 \%{ }^{10}$ of the recommendations were completed by the physician \\
\hline The pharmacist's recommendations are clinically significant & $\begin{array}{l}\text { Among real DRPs, } 83 \% \text { and } 49 \% \text { of recommendations were ranked as 'somewhat significant' or } \\
\text { higher and 'significant' or higher, respectively }\end{array}$ \\
\hline Patient treatment becomes more appropriate & $\begin{array}{l}\text { MAl was improved and the number of inappropriate drugs was reduced during hospital stay }{ }^{13} \text { and } \\
\text { also } 2 \text { weeks after discharge }\end{array}$ \\
\hline $\begin{array}{l}\text { Physicians and nurses are satisfied with the pharmacist in the team } \\
\text { and the benefit for the patient }\end{array}$ & $\begin{array}{l}\text { The stated benefit for the patients and for the healthcare team, and also the pharmacist performance } \\
\text { were valued as high, with a median and range within } 5-6 \text { on a } 6 \text { level scale }(1=\text { no, } 6=\text { large } \\
\text { benefit) })^{10} 11\end{array}$ \\
\hline Hospital readmission decreases & $\begin{array}{l}\text { Hospital readmission within } 3 \text { months due to DRPs decreased by } 55 \% \text {, from } 12 \text { to } 5.6 .{ }^{13} \text { Total } \\
\text { readmission was not affected }\end{array}$ \\
\hline
\end{tabular}


Table 3 Activities at discharge: summary of potential process benefits studied

\begin{tabular}{|c|c|}
\hline Potential benefit & Results and references \\
\hline $\begin{array}{l}\text { Medication report (without quality assurance) reduces error } \\
\text { rates in medication lists }\end{array}$ & $\begin{array}{l}\text { The proportion of patients without an error (measured based on what patients really take) in the } \\
\text { medication lists increased from } 34 \% \text { to } 68 \%^{3}\end{array}$ \\
\hline Decreased risk of clinical consequences & $\begin{array}{l}\text { The proportion of patients with a moderate or high risk of clinical consequences was reduced from } 32 \% \text { to } \\
16 \%^{3}\end{array}$ \\
\hline $\begin{array}{l}\text { Quality assured medication report in the LIMM discharge } \\
\text { information decreases error rates further }\end{array}$ & $\begin{array}{l}\text { The total number of errors decreased by } 45 \% \text { from } 12.0 \text { to } 4.8 \text { of medications. The proportion of patients } \\
\text { without errors increased from } 63 \% \text { to } 73 \%{ }^{5}\end{array}$ \\
\hline $\begin{array}{l}\text { The patient receives high quality discharge information written } \\
\text { by physicians }\end{array}$ & $\begin{array}{l}\text { Error rates in medication lists and medication reports decreased somewhat at the University Hospital wards } \\
\text { during } 1 \text { year of follow-up but the number of patients who received the information was still low ( } 31 \% \text { and } \\
27 \%)^{15}\end{array}$ \\
\hline Healthcare contacts after discharge decrease & The proportion of patients seeking care due to errors in medication lists decreased from $8.9 \%$ to $4.4 \%{ }^{16}$ \\
\hline
\end{tabular}

estimates of mortality and readmissions and the short follow-up, important treatment effects may have been overlooked. The Cochrane review also states that medication review should preferably be undertaken in the context of clinical trials and that high quality trials with a longer follow-up are needed before medication review should be implemented. ${ }^{1}$

In our work, we have not had the opportunity of performing high quality trials called for by the Cochrane review. Our team approach with routines, responsibilities and trust have been designed over several months to be effective and safe. It is therefore not possible to randomise a patient to a control group. A team based randomised study can only be performed in clusters, and we have not had the financial or organisational power to perform such a study. This is a limitation in the evidence base for the model. However, to our knowledge, there are no high quality studies on team based model interventions in healthcare where real patient outcomes have been studied. Interrupted time series have been suggested as a way to analyse outcomes. This is however problematic when the number of events (outcomes) in each cell is very low. Mortality and hospital readmissions due to DRPs are such outcomes. ${ }^{13} 14$

The focus of this paper has been on the process of drug therapy. According to Donobedian, ${ }^{7}$ the structure of care is also very important for quality and outcome. As part of the structure we need pharmaceuticals and diagnostic tools with a high level of evidence. We also need educated and trained pharmacists, physicians and nurses. With this in mind, several courses have been developed at Lund University for students and practitioners. The LIMM model has had a large impact on pharmacist education with a full scale MSc pharmacy programme. Here the LIMM model is the educational platform for training pharmacotherapy, communication, clinical skills, etc. ${ }^{20}$ The model has also received several national awards, including best innovation in Swedish healthcare, the gold scalpel. In southern Sweden,

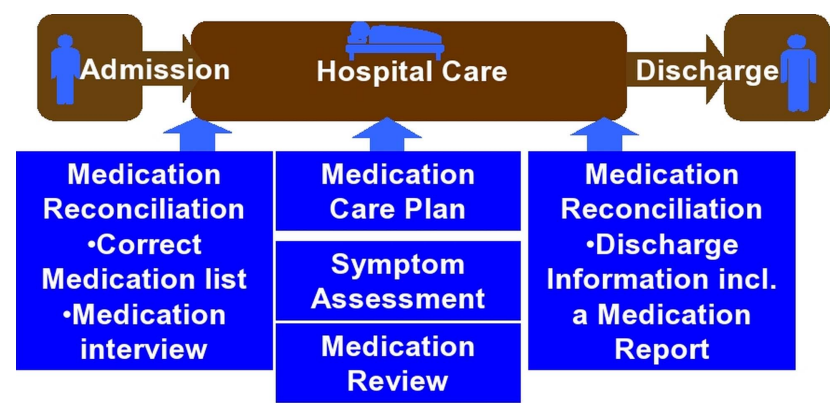

Figure 1 The Lund Integrated Medicines Management model. each hospital has employed a number of additional clinical pharmacists, paid by the local authorities, to perform medication reviews according to the LIMM model. Very recently there was an amendment to the Swedish constitution and also a national patient safety agreement that healthcare professionals must perform medication review and medication reconciliation during care transitions, and there have been economic incentives for this. This is expected to have a large impact on the need for clinical pharmacists, which is good for both patients and the pharmacy profession.

\section{Competing interests None.}

Provenance and peer review Not commissioned; not externally peer reviewed.

\section{REFERENCES}

1 Christensen $M$, Lundh A. Medication review in hospitalised patients to reduce morbidity and mortality. Cochrane Database Syst Rev 2013;2:CD008986.

2 Midlöv P, Bergkvist A, Bondesson $\AA$, et al. Medication errors when transferring elderly patients between primary health care and hospital care. Pharm World Sci 2005;27:116-20

3 Midlöv P, Holmdahl L, Eriksson T, et al. Medication report reduces number of medication errors when elderly patients are discharged from hospital. Pharmacy World Sci 2008;30:92-8

4 Bergkvist A, Midlöv $P$, Höglund $P$, et al. Improved quality in the hospital discharge summary reduces medication errors - LIMM: Landskrona Integrated Medicines Management. Eur J Clin Pharmacol 2009;65:1037-46.

5 Midlöv P, Bahrani L, Seyfali M, et al. Medication reconciliation interventions reduce medication errors when elderly patients are discharged from hospital. Int I Clin Pharm 2012;34:113-19.

6 Hellstrom L, Bondesson $\AA$, Höglund P, et al. Prediction of medication history errors at admission to hospital. BMC Clin Pharmacol 2012;12:9.

7 Donobedian A. An introduction to quality assurance in health care. New York: Oxford University Press, 2003.

8 Bondesson $\AA$, Holmdahl L, Midlöv P, et al. Acceptance and importance of clinical pharmacists LIMM-based recomendations. Int J Clin Pharm 2012:34:272-6.

9 Bondesson $\AA$, Hellström L, Eriksson T, et al. A structured questionnaire to assess patient compliance and beliefs about medicines taking into account the ordered categorical structure of data. J Eval Clin Pract 2009;15:713-23.

10 Bergkvist-Christensen A, Bondesson $\AA$, Höglund P, et al. The process of identifying, solving and preventing drug related problems in the LIMM-study. Int I Clin Pharm 2011;33:1010-18.

11 Bondesson $\AA$, Eriksson T, Holmdahl L, et al. In-hospital medication reviews reduce unidentified drug-related problems. Eur J Clin Pharmacol 2013;69:647-55.

12 Bergkvist $A$, Midlöv $P$, Höglund $P$, et al. A multi-intervention approach on drug therapy can lead to a more appropriate drug use in the elderly. LIMM-Landskrona Integrated Medicines Management. J Eval Clin Pract 2009;15:660-7.

13 Hellström LM, Bondesson Å, Höglund P, et al. Impact of the Lund Integrated Medicines Management (LIMM) model on medication appropriateness and drug-related hospital revisits. Eur J Clin Pharmacol 2011;67:741-52.

14 Hellstrom L, Höglund P, Bondesson $\AA$, et al. Clinical implementation of systematic medication reconciliation and review as part of the Lund Integrated Medicines Management model-impact on all-cause emergency department revisits. J Clin Pharm Therapeut 2012;37:86-92. 
15 Eriksson T, Höglund P, Holmdahl L, et al. Experiences from the implementation of structured patient discharge information for safe medication reconciliation at a Swedish university hospital. Eur J Hosp Pharm Sci 2011:2:42-9.

16 Midlöv P, Deierborg E, Holmdahl L, et al. Clinical outcomes from the use of Medication Report when elderly patients are discharged from hospital. Pharmacy World Sci 2008;30:840-5.

17 Eriksson T, Holmdahl L, Midlöv P, et al. The hospital LIMM-based clinical pharmacy service improves the quality of the patient medication process and saves time. Eur $J$ Hosp Pharm 2012;19:375-7.
18 Ghatnekar O, Bondesson $\AA$, Persson U, et al. Health economic evaluation of the Lund Integrated Medicines Management Model (LIMM) in elderly patients admitted to hospital. BMJ Open 2013;3:1. e001563.

19 Milos $V$, Rekman $E$, Bondesson $\AA$, et al. Improving the quality of pharmacotherapy in elderly primary care patients through medication reviews - a randomized controlled study. Drugs Aging 2013;30:235-46

20 Eriksson $\mathrm{T}$, Höglund $\mathrm{P}$, Thome $\mathrm{G}$, et al. Development of core competencies for a new master of pharmacy degree. Pharmacy Educ 2012;12:1-9. 